\title{
Kemampuan Mengidentifikasi Unsur-Unsur Pembentuk Iklan dalam Media Audio Visual pada Siswa Kelas VIII SMP Negeri 3 Tondano
}

\author{
Jenswita Indah Wuisang, Thelma Ivonne Maria Wengkang, Intama Jemmy Polii \\ Jurusan Pendidikan Bahasa dan Sastra Indonesia, Fakultas Bahasa dan Seni, Universitas Negeri \\ Manado \\ jenswitaw@gmail.com,thelmawengkang@yahoo.com,intamapolii@unima.ac.id
}

\begin{abstract}
Abstrak. Penelitian ini menggunakan metode deskriptif analitik. Teknik pengumpulan data yakni observasi, wawancara, dan tes. Sumber data penelitian adalah siswa kelas VIII D yang berjumlah 15 orang. Untuk menganalisis data teknik yang digunakan ialah menggabungkan analisis data kualitatif dan kuantitatif. Rumus yang digunakan untuk menganalisis data kuantitatif adalah persentase dengan rumus sebagai berikut: $\%=\mathrm{n} / \mathrm{N}$ x 100 . Hasil observasi menunjukkan bahwa siswa dalam mengidentifikasi unsur-unsur pembentuk iklan yang meliputi sumber, pesan, media, penerima, efek, dan umpan balik, dalam media audio visual yaitu berupa contoh iklan video yang berjudul "Cara Mencegah Virus Corona", sangat berperan aktif dan terlibat langsung saat mengerjakan soal dan dengan hasil yang memuaskan serta memberi suasana baru dalam pembelajaran lewat media audio visual yang dipakai sebagai sarana penyampaian materi sehingga pembelajaran ini dapat dikatakan berdampak positif dan menarik minat siswa. Dari hasil tes, nilai rata-rata klasikal yang diperoleh siswa dalam mengidentifikasi unsur-unsur pembentuk iklan adalah 92,8. Dapat disimpulkan bahwa siswa kelas VIII D SMP Negeri 3 Tondano berada pada kategori sangat mampu.
\end{abstract}

Kata Kunci: Mengidentifikasi, Unsur-Unsur Pembentuk Iklan, Media Audio Visual

\section{PENDAHULUAN}

Peran pendidikan menjadi sebuah acuan dalam keberhasilan pada pembelajaran di sekolah lewat guru sebagai pendidik dan siswa sebagai peserta didik. Komunikasi dua arah terjalin antara guru dan siswa saat pembelajaran sehingga sebagai seorang pendidik di sekolah, guru harus mampu mendidik dan mengajar para siswa agar dapat mengerti dan memahami, serta menguasai semua pelajaran yang sudah diajarkan. Dalam hal ini pendidikan sering pula diartikan sebagai kegiatan pengajaran. Pengajaran merupakan kegiatan interaksi antar guru dan siswa, dengan tujuan menyampaikan suatu pengetahuan, dalam hal ini guru sebagai sumber pengetahuan dan siswa sebagai penerimanya. Khusus pengajaran bahasa Indonesia, mata pelajaran ini sudah mulai diberikan sejak TK hingga perguruan tinggi. Meskipun demikian untuk setiap jenjang pendidikan, tujuan pengajaran bahasa Indonesia berbeda-beda. Untuk aspek pengetahuan pada tingkat SD lebih kecil dibanding dengan SMP, begitu juga pada tingkat perguruan tinggi akan berbanding lurus sehingga tingkat pengetahuannya lebih besar dan luas.

Dalam pengajaran bahasa Indonesia ada banyak materi yang diberikan di tingkat SMP salah satunya Teks Iklan. Iklan adalah pesan atau berita yang bertujuan untuk mendorong, membujuk khalayak ramai agar tertarik pada barang/jasa yang ditawarkan. Materi ini merupakan materi baru yang termasuk pada Kurikulum 2013 (K13). Sesuai dengan silabus, materi iklan mempunyai Kompetensi Dasar 3.3 yaitu mengidentifikasi informasi teks iklan, slogan atau poster (yang membuat bangga dan memotivasi) dari berbagai sumber yang dibaca dan didengar. Materi iklan ini khusus diajarkan pada siswa kelas VIII SMP/Mts sesuai dengan Buku Siswa Bahasa Indonesia Edisi Revisi 2017. Peneliti hanya memfokuskan pada cara mengidentifikasi unsur-unsur pembentuk iklan saja yakni ada enam unsur pembentuk iklan yaitu sumber, pesan, penerima, media, efek, dan umpan balik. Dengan dicantumkannya iklan di dalam kurikulum 2013 berarti siswa diharapkan memiliki kompetensi dalam mengidentifikasi unsur-unsur pembentuk iklan tersebut. Ironisnya ialah jika diberikan teks iklan siswa belum mampu mengidentifikasi informasi teks iklan, slogan atau poster (yang membuat bangga dan 
memotivasi) dari berbagai sumber yang dibaca dan didengar. Untuk mengatasi hal ini seorang guru harus menguasai bahan ajar sebelum ia memberikannya kepada siswa dalam hal ini yaitu keenam unsur pembentuk iklan. Sama halnya dengan proses komunikasi, harus ada sarana yang menjadi perantara dalam proses pengajaran.

Media merupakan sarana yang berfungsi untuk membantu dan memberi kemudahan bagi guru dalam proses pembelajaran. Dengan adanya media, akan mempengaruhi proses belajar siswa karena media menjadi salah satu hal penting untuk meningkatkan hasil belajar siswa. Sampai saat ini kerap kali masih banyak guru yang menemukan siswa dengan keadaan tidak mau belajar, malas, tidak tertarik alias bosan karena penggunaan media yang kurang menarik dan tidak sesuai atau bisa jadi karena gurunya yang monoton menggunakan media yang begitu saja. Hal seperti itulah yang tidak bisa dihindari apalagi sebagai guru ada banyak macam alasan yang akan keluar dari mulut siswa mulai dari cara mengajar guru yang sulit untuk dicerna dan dipahami, penggunaan media yang kurang menarik dan tidak sesuai, dan masih banyak lagi. Ini menjadi perhatian khusus bagi para guru. Untuk itu sebagai calon guru harus pandai dan terampil dalam memilih media apa yang cocok dengan materi yang akan diberikan sehingga dapat memotivasi siswa dan meningkatkan minat siswa dalam belajar lewat pembelajaran yang menarik, kreatif, dan menyenangkan sehingga memperoleh keberhasilan dalam mencapai tujuan pembelajaran.

Dari sekian banyak media yang ada, peneliti memilih media audio visual sebagai sarana penyampaian materi pembelajaran. Media audio visual adalah media yang memberi informasi melalui apa yang dilihat dan didengar. Alasan peneliti memilih media ini ialah karena dengan penggunaan media audio visual siswa dapat dengan fokus saat menyimak materi yang dalam bentuk suara dan gambar. Adapun keunggulan dari media audio visual menurut Sadiman (2009: 74) yaitu, (1) menarik perhatian untuk periode-periode yang singkat dari rangsangan luar lainnya, (2) gambar proyeksi bisa dibekukan untuk diamati dengan seksama, (3) ruangan tidak perlu digelapkan waktu menggunakannya, (4) menghemat waktu dan rekaman dapat dipakai berulang-ulang dengan fokus dapat menarik minat siswa. Dengan demikian, siswa dapat lebih mudah untuk mengerti lebih cepat dari biasanya lewat media ini. Oleh sebab itu guru harus mampu memberi suasana baru agar dapat tercipta pembelajaran yang menarik, kreatif dan menyenangkan. Bentuk iklan yang dipilih kali ini berupa contoh iklan dalam bentuk video yang akan diberikan kepada siswa agar semua siswa dapat terfokus pada contoh iklan yang sudah dibagikan ke masing-masing siswa otomatis itu akan merangsang proses menyimak mereka. Dari proses menyimak mereka dituntut agar dapat mengidentifikasi unsur-unsur pembentuk iklan sesuai dengan iklan yang sudah diberikan.

Berdasarkan latar belakang masalah yang ada maka penelitian ini diarahkan untuk menggambarkan "Kemampuan Mengidentifikasi Unsur-Unsur Pembentuk Iklan dalam Media Audio Visual pada Siswa Kelas VIII SMP Negeri 3 Tondano".

\section{METODE}

Metode yang digunakan dalam penelitian ini adalah metode deskriptif analitik. Metode ini digunakan untuk mengetahui kemampuan Siswa Kelas VIII SMP Negeri 3 Tondano dalam mengidentifikasi unsur-unsur pembentuk iklan dalam media audio visual. Penelitian ini dilaksanakan di SMP Negeri 3 Tondano, Kecamatan Tondano Selatan, Kabupaten Minahasa pada siswa kelas VIII D. Penelitian ini dilakukan pada semester genap tahun ajaran 2020/2021, mulai September - Oktober 2020.

Sumber data penelitian ini adalah siswa kelas VIII D SMP Negeri 3 Tondano yang berjumlah 15 orang. Teknik yang digunakan untuk mengumpulkan penelitian ini ialah observasi, wawancara, dan tes. Untuk menganalisis data teknik yang digunakan ialah menggabungkan analisis data kualitatif dan kuantitatif. Rumus yang digunakan untuk menganalisis data kuantitatif adalah persentase dengan rumus sebagai berikut: $\%=\mathrm{n} / \mathrm{N} \times 100$.

\section{HASIL DAN PEMBAHASAN}

\section{Deskripsi Pelaksanaan Pembelajaran}

Pelaksanaan pembelajaran mengikuti kurikulum (K13) yang meliputi, pendahuluan, kegiatan inti, dan penutup. 


\section{Pendahuluan :}

Pada kegiatan pendahuluan ini merupakan tahap awal atau bagian dari persiapan menuju pada kegiatan inti. Adapun kegiatan yang dilaksanakan pada tahap ini yaitu, mengucapkan salam, membuka pelajaran dengan doa, menyampaikan tujuan pembelajaran dan media yang akan digunakan, melakukan apersepsi seputaran materi yang akan dipelajari, dan memotivasi siswa agar dapat konsentrasi dan semangat dalam belajar. Berikut langkah-langkahnya:

(1) Guru menginformasikan ID dan Password lewat sosial media WhatsApp grup kelas VIII D Bahasa Indonesia, agar siswa dapat masuk ke Zoom (pembelajaran daring);

(2) Setelah semua siswa sudah masuk ke Zoom guru langsung menyampaikan untuk mengaktifkan video dan speaker siswa masing-masing,

(3) Kemudian sebelum masuk dalam kegiatan inti guru mengucapkan salam, dan menunjuk salah satu siswa untuk membuka kegiatan belajar mengajar dengan berdoa.

(4) Setelah itu guru menyampaikan tujuan pembelajaran dan melakukan apersepsi seputaran materi iklan, serta memotivasi siswa agar fokus dan semangat dalam belajar.

\section{Kegiatan Inti :}

Pada tahap ini, kegiatan yang dilaksanakan yaitu menyampaikan materi yang akan dipelajari, dan melakukan tes. Langkah-langkahnya sebagai berikut:

1) Guru menjelaskan materi tentang iklan lebih khusus pengertian unsur-unsur pembentuk iklan (sumber, pesan, media, penerima, efek, umpan balik), dan mengarahkan siswa untuk membuka buku paket halaman 33-34.

2) Setelah menjelaskan pengertiannya, kemudian guru memberikan contoh iklan layanan masyarakat yang berjudul "Cara Mencegah Virus Corona", dan mengarahkan mereka untuk mengidentifikasi unsur-unsur pembentuknya dalam iklan

3) tersebut. Tetapi sebelum itu guru memberikan pertanyaan kepada siswa, untuk mengukur kemampuan mereka apakah ada yang menyimak atau tidak tentang apa saja unsur-unsur pembentuk iklan yang sudah mereka belajar tadi dan sudah dijelaskan oleh guru.

4) Karena contoh iklan dalam bentuk audio visual atau berbentuk iklan video maka guru mengirimkan iklan tersebut di grup WhatsApp beserta soal yang akan dijawab oleh siswa.

5) Setelah itu, guru mengarahkan siswa untuk menjawab soal dan mengirimkan jawabannya dalam bentuk foto lewat WA, dan membawa tugas mereka di sekolah dengan mengikuti protokol kesehatan.

\section{Penutup :}

1) Guru dan siswa membuat refleksi dan kesimpulan dari materi yang telah dipelajari

2) Guru menyampaikan informasi untuk mengumpulkan tugas di sekolah jika sudah selesai, waktu yang diberikan selama 1-3 hari, karena penelitian bertepatan dengan Ujian Mid Semester Sekolah, dan pembelajaran hanya melalui via zoom atau pembelajaran daring.

3) Guru menutup pembelajaran dengan berdoa dan salam.

\subsection{Hasil Observasi}

Berikut hasil observasi dari kegiatan pembelajaran Mengidentifikasi Unsur-Unsur Pembentuk Iklan dalam Media Audio Visual iklan layanan masyarakat yang berjudul "Cara Mencegah Virus Corona". 
Tabel 1. Hasil Observasi Pelaksanaan Pembelajaran

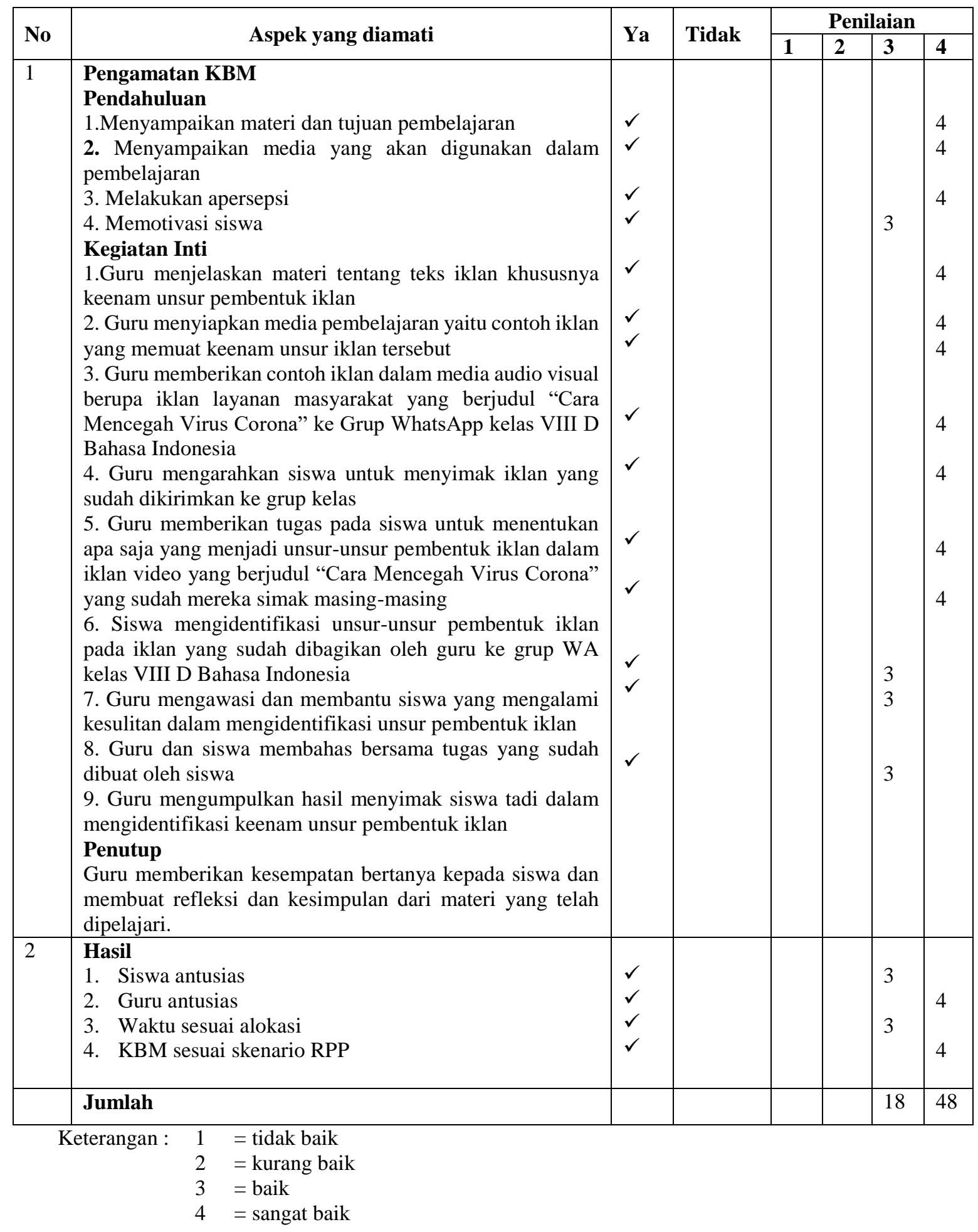

Hasil perhitungan penggunaan media Audio Visual oleh guru :

$$
\bar{X}=\frac{66}{17}=3,88
$$

Berdasarkan aspek-aspek di atas yang diamati dalam kegiatan belajar peneliti melibatkan seorang guru yang membantu menjadi observer selama kegiatan pembelajaran berlangsung dan peneliti mendapat kategori nilai baik dari observer. 


\subsection{Hasil Wawancara}

Hasil wawancara kali ini diambil dari siswa kelas VIII D dengan pedoman wawancara yang sudah dicantumkan pada Bab III di atas yaitu sebagai berikut :

a. Bagaimanakah kesan anda sebelum dan sesudah menggunakan media audio visual dalam mengidentifikasi unsur-unsur pembentuk iklan?

b. Sebelumnya media apa yang dipakai dalam mengidentifikasi unsur pembentuk iklan?

Di bawah ini merupakan rangkuman jawaban dari setiap siswa:

a. Pembelajaran mengidentifikasi unsur-unsur pembentuk iklan sangat mudah dipahami karena lewat media audio visual saya dapat mendengar suara dari iklan tersebut selain itu juga gambar-gambarnya menarik sehingga saya tidak bosan untuk menyimak iklannya sampai selesai, berbeda dengan sebelumnya iklan yang dipakai hanya berbentuk gambar yang dimuat dalam media cetak.

b. Media yang dipakai sebelumnya adalah media cetak seperti buku pelajaran bahasa Indonesia khusus Kelas VIII SMP.

Tabel 2. Kemampuan Mengidentifikasi Unsur-Unsur Pembentuk Iklan dalam Media Audio Visual Siswa Kelas VIII D SMP Negeri 3 Tondano

\begin{tabular}{|c|c|c|c|c|c|c|c|c|}
\hline \multirow{3}{*}{ Siswa } & \multicolumn{7}{|c|}{$\begin{array}{c}\text { Soal/Aspek yang dinilai } \\
\text { Skor }\end{array}$} & \multirow{3}{*}{$\begin{array}{l}\text { Jumlah } \\
\text { Skor }\end{array}$} \\
\hline & \multirow{2}{*}{$\begin{array}{l}\text { (1) Pengertian } \\
\text { Unsur-unsur } \\
\text { Pembentuk } \\
\text { Iklan } \\
\text { (40) }\end{array}$} & \multicolumn{6}{|c|}{$\begin{array}{c}\text { (2) Mengidentifikasi Unsur-unsur } \\
\text { Pembentuk Iklan }\end{array}$} & \\
\hline & & $\begin{array}{c}\text { Sumber } \\
(\mathbf{1 0})\end{array}$ & $\begin{array}{c}\text { Pesan } \\
\text { (10) }\end{array}$ & $\begin{array}{c}\text { Media } \\
(\mathbf{1 0})\end{array}$ & $\begin{array}{l}\text { Penerima } \\
\text { (10) }\end{array}$ & $\begin{array}{c}\text { Efek } \\
(10)\end{array}$ & $\begin{array}{c}\text { Umpan } \\
\text { Balik } \\
\text { (10) }\end{array}$ & \\
\hline 01 & 40 & 10 & 10 & 10 & 10 & 10 & 6 & 96 \\
\hline 02 & 40 & 10 & 10 & 10 & 10 & 10 & 9 & 99 \\
\hline 03 & 38 & 10 & 8 & 9 & 10 & 8 & 10 & 93 \\
\hline 04 & 40 & 10 & 10 & 10 & 10 & 10 & 10 & 100 \\
\hline 05 & 25 & 5 & 5 & 10 & 10 & 5 & 5 & 65 \\
\hline 06 & 40 & 10 & 10 & 10 & 10 & 10 & 10 & 100 \\
\hline 07 & 40 & 10 & 10 & 8 & 10 & 9 & 10 & 97 \\
\hline 08 & 40 & 10 & 9 & 8 & 8 & 9 & 7 & 91 \\
\hline 09 & 40 & 10 & 10 & 10 & 10 & 5 & 5 & 90 \\
\hline 010 & 40 & 5 & 9 & 10 & 10 & 7 & 7 & 88 \\
\hline 011 & 40 & 10 & 10 & 10 & 10 & 5 & 10 & 95 \\
\hline 012 & 40 & 10 & 10 & 10 & 10 & 10 & 10 & 100 \\
\hline 013 & 40 & 10 & 5 & 5 & 10 & 9 & 10 & 89 \\
\hline 014 & 35 & 10 & 9 & 8 & 10 & 7 & 10 & 89 \\
\hline 015 & 40 & 10 & 10 & 10 & 10 & 10 & 10 & 100 \\
\hline Jumlah & 578 & 140 & 135 & 138 & 148 & 124 & 129 & 1392 \\
\hline
\end{tabular}

\section{Rumus :}

$$
\begin{aligned}
\% & =\frac{n}{N} \times 100 \\
\% & =\frac{1.392}{15} \times 100 \\
& =\frac{1392}{15} \\
& =92,8 \%
\end{aligned}
$$

\section{Keterangan :}

$\mathrm{n}=1392 \mathrm{~N}=15$

Berdasarkan hasil pengolahan data di atas, jelaslah kemampuan siswa mengidentifikasi unsurunsur pembentuk iklan dalam media Audio Visual dapat dikategorikan sangat mampu karena rata-rata kelas yang diperoleh adalah $\mathbf{9 2 , 8 \%}$. 


\section{Tabel 3.Sebaran Kemampuan Siswa Mengidentifikasi Unsur-Unsur Pembentuk Iklan dalam Media Audio Visual}

\begin{tabular}{|c|c|c|c|c|}
\hline No. & Rentang & Kriteria & Jumlah & Persentase \\
\hline 1. & $90-100 \%$ & Sangat Mampu & 11 & $73,3 \%$ \\
\hline 2. & $80-89 \%$ & Mampu & 3 & $20 \%$ \\
\hline 3. & $70-79 \%$ & Cukup Mampu & - & - \\
\hline 4. & $60-69 \%$ & Kurang Mampu & 1 & $6,6 \%$ \\
\hline
\end{tabular}

Data di atas menunjukkan bahwa kemampuan siswa dalam mengidentifikasi unsur-unsur pembentuk iklan dalam media audio-visual, adalah sebanyak 11 siswa yang dikategorikan sangat mampu dan berada pada rentang nilai $90-100 \%$ dengan persentase $73,3 \%$, selanjutnya sebanyak 3 siswa yang dikategorikan mampu dan berada pada rentang nilai $80-89 \%$ dengan persentase $20 \%$, sedangkan yang dikategorikan cukup mampu dan berada pada rentang nilai 70-79\% tidak ditemukan, kemudian 1 siswa yang dikategorikan kurang mampu dan berada pada rentang nilai $60-69 \%$ dengan persentase $6,6 \%$.

Dengan demikian dapat disimpulkan bahwa iklan dalam media Audio Visual dapat memaksimalkan kemampuan siswa dalam mengidentifikasi unsur-unsur pembentuk (sumber, pesan, media, penerima, efek dan umpan balik) di dalam iklan tersebut khususnya dalam iklan layanan masyarakat yang berjudul "Cara Mencegah Virus Corona".

Hasil observasi pelaksanaan pembelajaran menunjukan bahwa berdasarkan aspek-aspek yang diamati dalam kegiatan belajar peneliti melibatkan seorang guru yang membantu menjadi observer selama kegiatan pembelajaran berlangsung dan peneliti mendapat kategori nilai baik dari observer.

Begitu pula dengan hasil wawancara yang diambil dari siswa, menunjukan bahwa guru dapat menciptakan suasana baru lewat penggunaan media audio visual yang dapat menarik minat siswa dalam belajar sehingga pembelajaran menjadi menyenangkan dan tidak membosankan.

Sehingga pemanfaatan media pembelajaran dapat dikatakan sangat berperan penting dalam pengajaran bahasa Indonesia khususnya dalam mengidentifikasi unsur-unsur pembentuk iklan, dalam hal ini media yang digunakan adalah media audio visual berupa iklan yang berbentuk video, yang kemudian dibagikan ke grup kelas VIII D SMP Negeri 3 Tondano lewat media sosial WhatsApp (WA). Penggunaan media audio visual memberi dampak positif bagi peserta didik, karena media audio visual tidak hanya disajikan dalam bentuk suara, tetapi juga didukung oleh gambar yang menarik perhatian siswa, sehingga mempermudah pemahaman siswa dalam menyimak hal ini sejalan dengan pendapat Susilana (2009 : 10) bahwa media audio visual mampu menghadirkan konsep abstrak maupun kongkret yang sulit dihadirkan secara nyata pada peserta didik sehingga peserta didik dapat dengan mudah mengidentifikasi unsur-unsur pembentuk iklan yang meliputi sumber, pesan, media, penerima, efek dan umpan balik pada iklan yang berjudul "Cara Mencegah Virus Corona".

Selain itu juga siswa sangat antusias dalam mengerjakan tugas hal ini ditandai dengan kerjasama yang baik antara siswa dan guru, ketepatan waktu dalam pengumpulan tugas, dan kemampuan siswa dalam menjawab soal yang diberikan dengan hasil yang memuaskan. Dalam penelitian ini juga dapat dinilai keterampilan menyimak siswa, dan didapatkan hasil kemampuan menyimak siswa termasuk dalam kategori sangat mampu karena lewat pembelajaran ini siswa dapat mengikuti langkah-langkah pembelajaran yang sudah dirancang sebelumnya oleh guru sehingga tujuan pembelajaran dapat tercapai.

Penelitian ini diperjelas dengan data-data di atas di mana hasilnya dapat menunjukkan bahwa kemampuan siswa tergolong dalam kriteria sangat mampu dalam mengidentifikasi unsur-unsur pembentuk iklan dalam media audio visual pada iklan yang berjudul "Cara Mencegah Virus Corona". Dengan nilai rata-rata klasikal yang diperoleh oleh siswa kelas VIII D SMP Negeri 3 Tondano yaitu 92,8\%, dengan rincian ada 11 siswa yang masuk dalam rentang nilai 90-100 dengan persentase 73,3\%, selanjutnya ada 3 siswa yang masuk dalam rentang nilai 80-89 dengan persentase 20\%, dan hanya 1 siswa yang masuk dalam rentang nilai 60-69 dengan persentase 6,6\%. 


\section{KESIMPULAN}

Berdasarkan hasil penelitian dan pembahasan, dapat ditarik kesimpulan bahwa kemampuan siswa dalam mengidentifikasi unsur-unsur pembentuk iklan yang meliputi sumber, pesan, media, penerima, efek, dan umpan balik pada iklan yang berjudul "Cara Mencegah Virus Corona" dalam media audio visual pada siswa kelas VIII D SMP Negeri 3 Tondano dikategorikan sangat mampu dengan nilai ratarata klaksikal 92,8\%.

\section{DAFTAR PUSTAKA}

Ali. Muhammad. 1987. Penelitian Kependidikan Prosedur dan Strategi. Bandung: Angkasa.

Arief S. Sadiman, dkk. 2009. Media Pendidikan, Pengertian, Pengembangan, dan Pemanfaatannya. Jakarta: Rajawali Press.

Arikunto, S. 2009. Prosedur Penelitian Suatu Pendekatan Praktik. Edisi Revisi 6. Jakarta: Rineka Cipta.

Depdikbud. 1993. Kamus Besar Bahasa Indonesia. Jakarta: Balai Pustaka.

Kementrian Pendidikan dan Kebudayaan Republik Indonesia. 2017. Buku Siswa Bahasa Indonesia Kelas VIII SMP/MTs. Edisi Revisi. Jakarta: Kementrian Pendidikan dan Kebudayaan.

Nurbiana Dhieni, dkk. 2008. Metode Pengembangan Bahasa. Jakarta: Universitas Terbuka.

Rudi Susilana, Cepi Riyana. Media Pembelajaran. Bandung: CV Wacana Prima.

Sugiyono. 2009. Metode Penelitian Kuantitatif, Kualitatif dan R\&D. Bandung: Alfabeta. 